\title{
A NEW SEX-LINKED MUTANT SHORT WING IN AEDES AEGYPTI
}

\author{
D. K. UPPAL*, C. F. CURTIS $†$ and V. K. SONI \\ WHO/ICMR Research Unit on the Genetic Control of Mosquitos, New Delhi, India
}

Received 11.vii.75

\section{SUMMARY}

A spontaneous recessive sex-linked mutant short wing has been discovered in the mosquito Aedes aegypti. It is situated less than one cross-over unit from the sex determining locus. In homozygous females, flight is impaired and the survival and fecundity is markedly subnormal.

Two possible uses of this gene for genetic control operations are envisaged: (a) to provide automatic sexing of males for release and (b) enhancement of the population control potential of other available genetics systems.

A PREviousLy unreported, spontaneous, recessive mutation short wing (sw) has been found in the mosquito Aedes aegypti. The mutant was picked up in inbred lines derived from a back-crossing programme of the JY multiple marker stock with ROGK background (received from the University of Notre Dame) to the Delhi wild type strain. In the homozygous condition this gene causes shortening of the wings. In normal adults the wing completely covers six abdominal segments (Plate l, left), while in the mutants it never extends beyond the 5 th segment and sometimes covers only three or four segments. Mutant females with the more extreme expression do not survive beyond eclosion, but those in which the wings reach to the 4 th or 5 th segment (Plate 1, right) survive as adults, though their life-span is shortened.

Pupae homozygous for sw appear indistinguishable from wild type, but after emergence, the short wing females cannot fly from the water surface. Many of them eventually drown, but a proportion manage to walk away and survive. To avoid this heavy mortality, short wing female pupae, after sexing, were placed on wet filter paper for eclosion and, with this technique, survival during the first hours of female adult life was normal. Short wing males are able to fly normally, apparently because the male's body weight is about half that of a female (Ghristophers, 1960). Adult short wing females in laboratory cages seldom fly or take part in swarming and stay mostly in the lower half of the cage. Therefore, cotton wool pads soaked in 1 per cent glucose solution and the blood source (anaesthetised mice) were offered to them on the floor of the cage to ensure that they fed. For oviposition, petridishes or shallow bowls lined with wet filter paper were provided which were accessible and safe for these females.

Adult short wing females survived for an average of 17 days in laboratory cages. Table 1 shows their longevity and fecundity compared with wild type. It is clear from the data that survival and fecundity were subnormal in the mutant homozygotes.

By various crosses (table 2) it was shown that inheritance of this gene is

* Research Officer, ICMR; present address : Dept. of Zoology Khalsa, College, University of Delhi, Delhi 110006, India.

$\uparrow$ Geneticist, WHO; present address: VBC, WHO Headquarters, Geneva, Switzerland.

† Biological Aide, ICMR. 
sex-linked and the gene is very close to the sex locus $m / M$, with less than 1 per cent crossing over. At present this mutant is being maintained in the laboratory by crossing $s w / s w$ females and $s w /+$ males with the mutant gene linked to the $m$ gene. With minimal inspection and elimination of cross-over products the line can be maintained indefinitely.

\section{TABLE 1}

Comparison of adult survival and female fecundity of short wing homozygotes and wild type controls in laboratory cages. Both cages were initiated from 100 females and 100 males

\begin{tabular}{|c|c|c|c|c|c|}
\hline Week & $\begin{array}{l}\text { No. females } \\
\text { surviving on } \\
\text { median day }\end{array}$ & $\begin{array}{l}\text { No. males } \\
\text { surviving on } \\
\text { median day }\end{array}$ & $\begin{array}{l}\text { Total eggs } \\
\text { produced } \\
\text { in week }\end{array}$ & $\begin{array}{c}\text { Fecundity (eggs/ } \\
\text { surviving } \\
\text { female/week) }\end{array}$ & $\begin{array}{l}\text { Accumulated } \\
\text { number } \\
\text { of eggs }\end{array}$ \\
\hline \multicolumn{6}{|c|}{ Short wing: } \\
\hline 1 & 90 & 97 & 2275 & 25 & 2275 \\
\hline 2 & 82 & 78 & 3645 & 44 & 5920 \\
\hline 3 & 35 & 55 & 2410 & 69 & 8330 \\
\hline 4 & 21 & 31 & 666 & 32 & 8996 \\
\hline 5 & 15 & 15 & 393 & 26 & 9389 \\
\hline 6 & 0 & 6 & - & - & - \\
\hline \multicolumn{6}{|c|}{ Wild type control: } \\
\hline 1 & 94 & 88 & 6900 & 73 & 6900 \\
\hline 2 & 76 & 64 & 11552 & 152 & 18452 \\
\hline 3 & 69 & 37 & 7199 & 104 & 25651 \\
\hline 4 & 59 & 20 & 7146 & 121 & 32797 \\
\hline 5 & 54 & 10 & 4418 & 81 & 37215 \\
\hline 6 & 48 & 8 & - & - & - \\
\hline
\end{tabular}

TABLE 2

Data on inheritance of the sw gene

\begin{tabular}{|c|c|c|c|c|c|c|}
\hline \multicolumn{3}{|c|}{ Mating } & \multicolumn{4}{|c|}{ Progeny phenotypes } \\
\hline & ơ & $0^{1} \sigma^{*}$ & & & & \\
\hline 1. & $\frac{m s w}{m s w} \times$ & $\frac{M+}{m s w}$ & $\frac{t}{1}$ & $\frac{s w}{228}$ & $\frac{+}{247}$ & $\frac{s w}{2}$ \\
\hline 2. & $\frac{m s w}{m s w} \times$ & $\frac{M+}{m+}$ & 921 & 一 & 886 & - \\
\hline 3. & $\frac{m+}{m s w} \times$ & $\frac{M+}{m s w}$ & 347 & 316 & 663 & 2 \\
\hline 4. (a) & $\frac{m+}{m+} \times$ & $\frac{M+}{m s w}$ & 198 & - & 203 & 一 \\
\hline $\begin{array}{l}\text { (b) } \\
\text { (c) }\end{array}$ & $\begin{array}{l}\text { Inbreec } \\
\text { Inbreec }\end{array}$ & ling of $4(a)$ & $\begin{array}{l}285 \\
988\end{array}$ & $\overline{147}$ & $\begin{array}{r}308 \\
1080\end{array}$ & $\overline{1}$ \\
\hline
\end{tabular}

The linkage data on sex-linked genes in Aedes aegypti are summarised by Bhalla and Craig (1970). The sw gene is the most closely sex-linked marker yet found in Aedes aegypti, apart from the meiotic driving distorter factor (Hickey and Craig, 1966), but the latter appears to be a part of the sexdetermining gene or chromosomal region.

There are distinct possibilities for using the sw mutant in the genetic control of $A$. aegypti. Sexing of mosquitos for genetic control releases is very 
important so that virtually only males (the non-biting sex) are released. The sw gene might be used for sexing instead of the existing method based on pupal size (Sharma et al., 1972; Ansari et al., 1975) or in addition to this system to obtain further refinement of the separation process. As already shown, a stock with $s w / s w$ females and $M+/ m$ sw males would continue to produce almost entirely short wing females and normal males and it seems probable that after emergence the flying males could be induced to separate themselves from the flightless females. Any females that managed to join the males would be of little consequence because they are unlikely to be able to bite after release.

Wingless mutants were suggested by LaChance and Knipling (1962) as one form of conditional lethal which could be employed for population control and the sw mutant might usefully be integrated with other genetic control systems in this species which are already available, for example the double translocation heterozygote T1/T3 (Uppal et al., 1974) or T1/T3 with sex ratio distortion (Suguna and Curtis, 1974). Tests of the population control potential of these systems in outdoor cages (Curtis et al., 1975) confirmed that a proportion of fertile T3T3 homozygotes are generated in the wild population in the generations following releases. If the sw gene were incorporated into the T3/T3 stock, which is the female parent of the double heterozygotes for release, most of the T3/T3 segregants in the wild population would be sw/sw because of the linkage of sw and T3 to sex. Such flightless females would be unlikely to be able to bite and reproduce under wild conditions. Hence the effective fertility of the population in the generations following releases would be reduced, but, on the other hand, the selective killing of T3/T3 females would eliminate the T3 translocation relatively rapidly from the residual population and speed the restoration of normal wild type fertility. Computer simulations indicate that the overall number of genetic deaths following release of a given number of double heterozygote males would be approximately the same whether or not the sw gene was incorporated. However, it is considered that on balance the incorporation of $s w$ into the system would be a beneficial feature, as the concentration of as much sterility as possible into the generations immediately following the releases gives the best chance of overcoming the recovery potential of the population and achieving effective control.

The efficient employment of sw either as a sexing device or a control system, or both, would depend upon the development of techniques and equipment to secure adequate survival and oviposition of sw/sw females under mass rearing conditions.

Acknowledgments.-We thank M. K. Gupta, Miss V. Tandon and K. N. Joshi for their conscientious technical assistance. We are grateful to Dr K. R. P. Singh for suggestions with regard to maintenance methods for the mutant. We are indebted to Dr G. D. Brooks for his support and encouragement and for his comments on the manuscript.

\section{REFERENCES}

ANSARI, M. A., SINGH, K. R. P., AND BROOKS, G. D. 1975. The development of procedures for mass rearing of Aedes aegypti for feasibility studies on the use of the sterile male technique. WHO/VBC 75.560.

BHALLA, s. C., AND CRAIG, G. B. 1970. Linkage analysis of chromosome 1 of Aedes aegypti. Can. 7. Genet. Cytol., 12, 635-650. 
GHristophers, s. R. 1960. Aedes aegypti (L.) the Tellow Fever Mosquito, Cambridge University Press.

GURTIS, C. F., GROVER, K. K., SUGUNA, S. G., UPPAL, D. K., DIETZ, K., AGARWAL, H. V., AND KAZMI, s. J. 1975. Comparative field cage tests of the population suppressing efficiency of three genetic control systems for Aedes aegypti. WHO/VBC/75.529. Heredity (in press). HIGKEY, W. A., AND GRAIG, G. B. 1966. Genetic distortion of sex ratio in a mosquito, Aedes aegypti. Genetics, 53, 1177-1196.

LaGhaNGE, L. E., AND KNIPLING, E. F. 1962. Control of insect populations through genetic manipulations. Ann. Ent. Soc. Amer., 55, 515-520.

SHARMA, V. P., PATTERSON, R. S., AND FORD, H. R. 1972. A device for the rapid separation of male and female pupae. Bull. Wld Hlth Org., 47, 429-432.

suguna, s. G., GURTIS, G. F. 1974. Sex ratio distorter strains in Aedes aegypti. 7. Com. Dis., 6, 102-105.

UPPAL, D. K., GURTIS, G. F., AND RAI, K. s. 1974. A double translocation heterozygote in Aedes aegypti. 7. Com. Dis., 6, 98-101. 


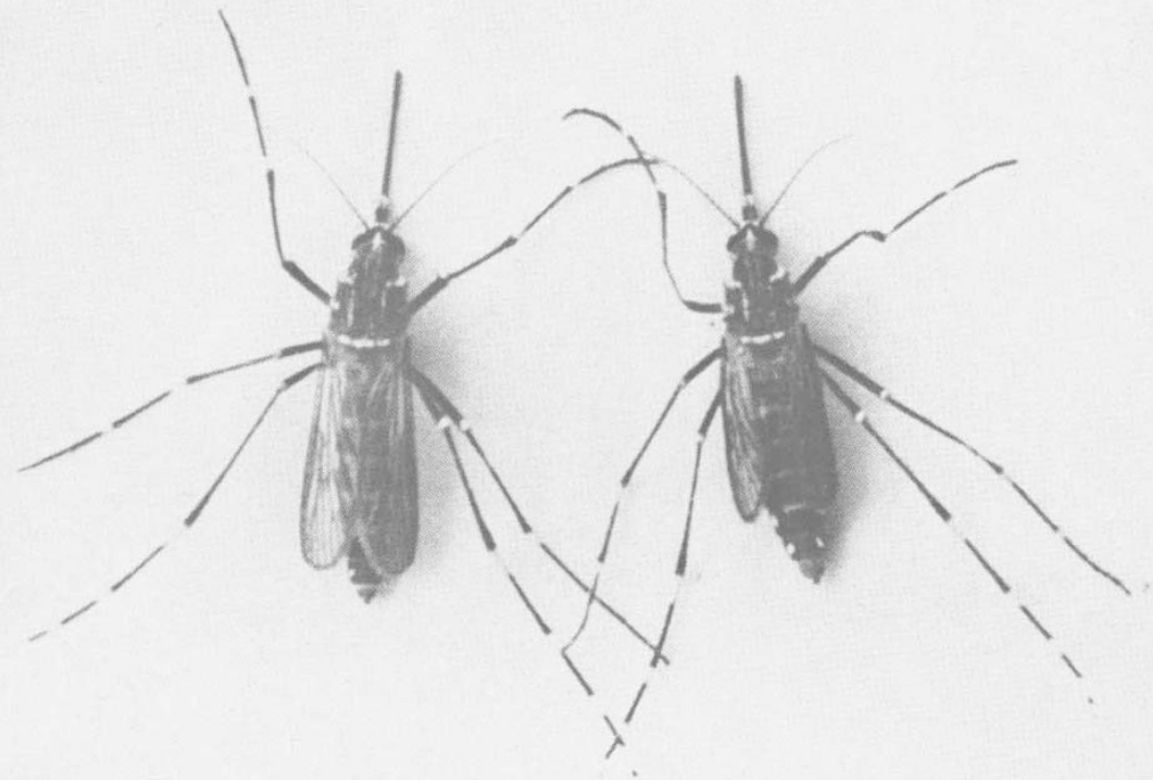

Plate I 